\title{
PEMBERIAN KREDIT KEPADA DEBITUR DILUAR ANGGOTA LPD DESA PAKRAMAN PADANGSAMBIAN DITINJAU DARI PERDA NO 3 TAHUN 2017*
}

Oleh:

\author{
Dewa Putu Thresna Andyanatha** \\ I Wayan Wiryawan ${ }^{* * *}$ \\ I Made Dedy Priyanto***
}

Bagian Hukum Perdata Fakultas Hukum Universitas Udayana

\begin{abstract}
ABSTRAK
LPD merupakan suatu lembaga keuangan komunitas masyarakat desa. Dalam pelaksanaan bidang usahanya sering dijumpai adanya suatu penyimpangan dimana LPD dapat memberikan pinjaman kredit kepada debitur diluar anggota Desa Pakraman.Namun adanya syarat yang mengharuskan debitur diluar anggota desa pakraman menyertakan perjanjian kerjasama antar desa dalam permohonan perjanjian kredit. Dalam hasil penelitian dapat diketahui pelaksanaan pasal 7 ayat (1) huruf c Perda No 3 tahun 2017 tentang LPD kurang efektif.Faktor penyebab diperbolehkannya debitur diluar anggota desa mendapatkan pinjaman kredit di LPD tanpa adanya kerjasama antar desa adalah LPD masih menggunakan ketentuan peraturan lama, lebih diutamakan adanya jaminan dan banyaknya pinjaman kredit yang dapat diberikan, asas kekeluargaan yang dianut LPD sehingga mengesampingkan peraturan yang berlaku.

Penulisan jurnal ini menggunakan jenis penelitian yuridis empiris, serta pendekatan perundang-undangan dan pendekatan fakta. Penulisan jurnal ini bertujuan untuk mengetahui bagaimana pelaksanaan Pasal 7 ayat (1) huruf c Perda No 3 tahun 2017 tentang LPD di LPD Desa Pakraman Padangsambian dan apa saja faktor penyebab diperbolehkannya debitur diluar anggota Desa Pakraman melakukan pinjaman kredit di LPD Desa Pakraman Padangsambian tanpa adanya kerjasama antar desa.
\end{abstract}

Kata kunci: LPD, Perjanjian Kredit, Kerjasama antar desa

\footnotetext{
*Penulisan karya ilmiah merupakan ringkasan skripsi.

${ }_{* * *}^{* *}$ ewa Putu Thresna Andyanatha, 1503005168, Mahasiswa S1 Reguler Pagi FH UNUD

${ }^{* * *}$ I Wayan Wiryawan adalah dosen Fakultas Hukum Universitas Udayana

${ }^{* * * *}$ I Made Dedy Priyanto adalah dosen Fakultas Hukum Universitas Udayana
} 


\section{ABSTRACT}

The LPD is a village community financial institution. In the implementation of the business sector, it is often found that there are irregularities in which the LPD can provide credit loans to debtors outside the members of the Pakraman Village.However, there are conditions that require debtors outside Pakraman village members to include cooperation agreements between villages in the credit agreement application. In the results of the study, it can be seen that the implementation of article 7 paragraph (1) letter $c$ of Regulation No. 3 of 2017 concerning LPDs is less effective, the obstacle of not implementing this article is ignorance of the law, the LPD prioritizes guarantees, and the absence of sanctions related to violations. Factors that may allow debtors outside of village members to obtain credit loans at LPD without cooperation between villages are that LPDs still use the provisions of the old regulations, preferably guarantees and the number of credit loans that can be given, the family principle adopted by the LPD to override applicable regulations.

This journal uses a type of empirical juridical research, as well as a legislative approach and factual approach. Writing this journal aims to find out how the implementation of Article 7 paragraph (1) letter c Perda No 32017 concerning LPD in LPD Pakraman Padangsambian Village and what are the factors that allow debtors outside Pakraman Village members to make credit loans at LPD Pakraman Padangsambian Village without cooperation between villages.

Keywords: LPD, Credit Agreement, Cooperation between villages

\section{PENDAHULUAN}

\section{$1.1 \quad$ Latar Belakang}

LPD adalah suatu bentuk implementasi pembagian urusan pemerintahan yakni otonomi daerah sebagai lembaga keuangan yang memiliki visi misi yang baik untuk memajukan kegiatan perekonomian desa namun tetap sejalan dengan nilai-nilai budaya dimana LPD merupakan suatu lembaga keuangan komunitas yang dibentuk oleh suatu satuan komunitas, beroperasi di wilayah komunitas, melayani transaksi keuangan di lingkungan atau 
untuk kepentingan anggota komunitas, dan untuk memenuhi tujuan-tujuan komunitas. ${ }^{1}$ Berdiri dan berkembangnya LPD di Bali pada dasarnya untuk pembangunan di tiap - tiap desa adat atau desa pekraman sebagai kekuatan untuk menjaga adat dan budaya Bali yang merupakan suatu strategi baru dalam meningkatkan sumber pendanaan khususnya terhadap anggota masyarakat setempat. $^{2}$

LPD diatur dalam Peraturan Daerah Provinsi Bali Nomor 3 tahun 2017 tentang LPD. Sesuai dengan ketentuan Pasal 2 Ayat (1) dan Pasal 3 Peraturan Daerah Provinsi Bali Nomor 3 tahun 2017 tentang LPDbahwa LPD adalah badan usaha keuangan milik desa dan melaksanakan kegiatan operasional usaha di lingkungan Desa dan untuk Krama Desa. LPD memiliki fungsi utama sebagai lembaga simpan-pinjam. Pasal 7 Ayat (1) Peraturan Daerah Provinsi Bali Nomor 3 tahun 2017 tentang LPD menyatakan secara jelas pembatasan lingkup bidang usaha dari LPD yang dipertegas dalam sub b yaitu memberikan pinjaman kepada krama desa dan desa pakraman itu sendiri yang nantinya dapat digunakan untuk mengadakan upacara-upacara keagamaan maupun melakukan pembangunan desa.Kegiatan simpan pinjam tersebut hanya dapat dilakukan oleh anggota Desa Pakraman sebagai debitur dengan LPD sebagai kreditur. LPD adalah lembaga keuangan yang mandiri dan berada dibawah naungan Desa Adat, mandiri disini berarti dalam mendirikan, menjalankan, dan mengembangkan organisasi

${ }^{1}$ I Nyoman Nurjaya, dkk, 2011, Landasan Teoritik Pengaturan LPD Sebagai Lembaga Keuangan Komunitas Masyarakat Hukum Adat Di Bali, Udayana University Press, Denpasar, h. 37.

${ }^{2}$ I Gede Made Gandhi Dwinata dkk, 2015,"Eksistensi Lembaga Perkreditan Desa Setelah Dikeluarkannya Undang - Undang Nomor 1 Tahun 2013 Tentang Lembaga Keuangan Mikro", Jurnal Fakultas Hukum Universitas Udayana, Denpasar, h. 2. URL : https://ojs.unud.ac.id/.index.php/kerthasemaya/.article/download/13163/8845. Diakses tanggal 20 Mei 2019. 
ditentukan oleh kekuatan sendiri, tidak dikendalikan oleh pihak lain diluar organisasi. ${ }^{3}$ Berbagai keuntungan melakukan pinjaman kredit di LPD adalah diantaranya jarak yang dekat dari tempat tinggal, bunga yang rendah, dan LPD lebih mengutamakan adanya asas kekeluargaan dan kepercayaan dalam praktek usahanya, dimana pengutamaan asas kekeluargaan dan kepercayaan ini sering menimbulkan masalah khususnya dalam perjanjian kredit.

Selanjutnya dalam Pasal 7 ayat (1) huruf c dinyatakan bahwa debitur diluar anggota Desa Pakraman diperbolehkan melakukan pinjaman kredit di LPD namun dengan suatu syarat yakni adanya kerjasama tertulis antara Desa Pakraman Padangsambian dengan Desa tempat tinggal calon debitur, namun dalam implementasi pemberian pinjaman kredit tidak ada kerjasama antar desa yang dilakukantetapi pinjaman kredit tetap dapat diberikan, maka telah terjadi suatu bentuk pelanggaran. Berdasarkan uraian latar belakang tersebut, maka dalam hasil penelitian dapat diketahui pelaksanaan bidang usaha LPD ditinjau dari Perda No 3 tahun 2017 tentang LPD dan faktor penyebab diperbolehkannya debitur diluar anggota Desa Pakraman mendapatkan pinjaman kredit di LPD Desa Pakraman Padangsambian tanpa adanya kerjasama antar desa.

\subsection{Rumusan Masalah}

Berdasarkan latar belakang masalah yang telah diuraikan diatas, adapun rumusan masalah yang dapat dikemukakan adalah sebagai berikut:

${ }^{3}$ I Made Udiana, 2015, Kedudukan Dan Kewenangan Pengadilan Hubungan Industrial, Udayana University Press, Denpasar, h. 45 
1. Bagaimana pelaksanaan Pasal 7 ayat (1) huruf c Perda No 3 tahun 2017 tentang LPD di LPD Desa Pakraman Padangsambian?

2. Apakah faktor penyebab diperbolehkannya debitur diluar anggota Desa Pakraman melakukan pinjaman kredit di LPD Desa Pakraman Padangsambian tanpa adanya kerjasama antar desa?

\subsection{Tujuan Penulisan}

1. Untuk mengetahui bagaimana pelaksanaan Pasal 7 ayat (1) huruf c Perda No 3 tahun 2017 tentang LPD di LPD Desa Pakraman Padangsambian.

2. Untuk mengetahui apa saja faktor penyebab diperbolehkannya debitur diluar anggota Desa Pakraman melakukan pinjaman kredit di LPD Desa Pakraman Padangsambian tanpa adanya kerjasama antar desa.

\section{ISI MAKALAH}

\subsection{Metode Penelitian}

Dalam penulisan karya ini menggunakan jenis penelitian yuridis empiris yang melihat adanya suatu kesenjangan antara peraturan perundang-undangan yang mengatur dengan keadaan yang ada di masyarakat, penelitian empiris digunakan untuk menganalisis hukum yang dilihat sebagai perilaku masyarakatyang berpola dalam kehidupan masyarakat yang selalu berinteraksi dan berhubungan dalam aspek kemasyarakatan. 4 Adapun jenis pendekatan yang digunakan adalah jenis pendekatan perundang-undangan dan jenis

${ }^{4}$ Bambang Sunggono, 2003, Metodologi Penelitian Hukum, PT Raja Grafindo Perkasa, Jakarta, h. 43. 
pendekatan fakta

\subsection{Hasil dan Pembahasan}

\subsubsection{Pelaksanaan Pasal 7 Ayat (1) Huruf c Perda NO 3 Tahun 2017 tentang LPD di LPD Desa Pakraman Padangsambian}

Esensi unit Desa Pakraman melalui LPD sebagai salah satu lembaga keuangan merupakan agen pengembangan yang strategis. Hal ini terlihat dari banyaknya dana masyarakat berupa tabungan dan deposito yang dapat dihimpun dalam kurun waktu tertentu serta kemampuan LPD memberikan bantuan berupa pinjaman kepada anggotanya. ${ }^{5}$ Dalam Pasal 7 ayat (1) huruf c Perda No 3 tahun 2017 dijelasakan bahwa LPD dapat memberikan pinjaman kredit kepada debitur yang berada diluar lingkup Desa Pakraman dalam hal ini Desa Pakraman Padangsambian, namun dalam memberikan pinjaman kredit tersebut diperlukan adanya suatu syarat yaitu perlu diadakannya kerjasama antara desa Padangsambian dengan desa tempat tinggal calon debitur yang selanjutnya kerjasama ini disebut kerjasama antar desa. I Made Astrawijaya sebagai kepala LPD Desa Pakraman Padangsambian mengatakan dalam pemberian kredit oleh LPD Desa Pakraman Padangsambian kepada debitur diluar anggota Desa Pakraman tidak ada suatu kerjasama antar desa yang dilakukan dimana hal ini telah melanggar ketentuan Pasal 7 ayat (1) huruf c Perda No 3 tahun 2017 tentang LPD. (Wawancara pada tanggal 26 Februari 2019 di LPD Desa Pakraman Padangsambian)

Diperbolehkannya debitur diluar anggota Desa Pakraman melakukan pinjaman kredit di LPD Desa Pakraman Padangsambian tanpa adanya kerjasama antar desa menyebabkan

${ }^{5}$ Sri rahayu Gorda, 2016, Wrddhi Grhiyad Prinsip Perjanjian Kredi Mmenurut Hindu, Udayana Press, Denpasar,h. 99. 
terjadinya suatu pelanggaran. Pelanggaran yang dilakukan oleh LPD tersebut menyebabkan adanya suatu akibat hukum bagi LPD maupun perjanjian kredit yang telah dilakukan dimana Pelaksanaan pemberian pinjaman kredit kepada calon debitur diluar anggota Desa Pakraman tidak sesuai dengan ketentuan Perda No 3 tahun 2017 tentang LPD pada pasal 3 dan Pasal 7 ayat (1) huruf b dan c dimana LPD dapat memberikan pinjaman kredit kepada masyarakat anggota desa pakraman dan masyarakat diluar anggota desa pakraman namun dengan suatu syarat yakni adanya suatu kerjasama antar Desa Pakraman Padangsambian dengan desa tempat tinggal calon debitur. LPD melanggar ketentuan pada Pasal 1320 KUHPerdata mengenai syarat sahnya perjanjian poin ke 4 yakni suatu sebab yang terlarang dimana Perda No 3 tahu 2017 tentang LPD tidak memperbolehkan hal tersebut dilakukan dalam praktek pemberian pinjaman kredit. Sehingga perjanjian kredit debitur diluar anggota Desa Pakraman tanpa adanya kerjasama antar desa adalah batal demi hukum, dan dianggap tidak pernah ada. Perjanjian kredit tersebut tidak memiliki kekuatan hukum karena dinyatakan tidak sah berdasarkan Pasal 1320 KUHPerdata. Namun dalam Perda No 3 tahun 2017 tentang LPD tidak memuat sanksi bagi LPD maupun debitur terkait pelanggaran yang dilakukan.Dengan demikian pelaksanaan Pasal 7 ayat (1) huruf c Perda No 3 tahun 2017 tentang LPDdi LPD Desa Pakraman Padangsambian berjalan kurang efektif. 


\subsubsection{Faktor Penyebab Diperbolehkannya Debitur Diluar Anggota Desa Pakraman Melakukan Pinjaman Kredit Di LPD Desa Pakraman Padangsambian Tanpa Adanya Kerjasama Antar Desa}

Lembaga Perkreditan Desa (LPD) sebagai salah satu wadah kekayaan desa, menjalankan fungsinya dalam bentuk usahausaha untuk meningkatkan taraf hidup masyarakat desa serta sebagai penunjang kegiatan pembangunan desa. ${ }^{6}$ Dalam hal pemberian pinjaman kredit kepada calon debitur diluar anggota desa yang dilakukan oleh LPD Desa Pakraman Padangsambian, LPD memiliki suatu pandangan tersendiri yang menyebabkan diperbolehkannya suatu pinjaman ini dilakukan. Faktor diperbolehkannya debitur diluar anggota Desa Pakraman melakukan pinjaman kredit di LPD Desa Pakraman Padangsambian akan dibagi menjadi dua yaitu faktor internal dan faktor eksternal.

1) Faktor Internal

1. LPD masih menggunakan peraturan yang lama yakni Perda No 8 tahun 2002 tentang LPD, dimana Perda tersebut kurang jelas mengatur mengenai pinjaman kredit kepada calon debitur diluar anggota Desa Pakraman. Walaupun telah dijelasakan bahwa LPD hanya memberikan pinjaman kepada kramadesa. Faktor ini lebih kepada ketidaktahuan akan hukum lebih baru yang berlaku yang mengatur mengenai LPD.

${ }^{6}$ Komang Gede Indra Parisuda dkk, 2013, "Pelaksanaan Pemberian Kredit Kepada Anggota Masyarakat Pada Lembaga Perkreditan Desa Di Kota Denpasar", Jurnal Fakultas Hukum Universitas Udayana, Denpasar, h. 1. URL: https://ojs.unud.ac.id/index.php/kertha semaya/ar ticle/view/5256. Diakses tanggal 22 Mei 2019 
2. Pihak LPD lebih mengutamakan adanya suatu jaminan benda bergerak maupun tidak bergerak dari si calon debitur dan mengesampingkan tempat tinggal debitur yang dalam konteks ini berada diluar cakupan Desa Pakraman Padangsambian.

3. LPD mengutamakan banyaknya pinjaman kredit yang dapat diberikan, maka LPD akan memperoleh penghasilan lebih dari bunga yang dapat dihimpun dari nasabah/debitur. Dimana selanjutnya dana bunga yang terhimpun tersebut dapat lebih dialokasikan untuk kepentingan desa dan kesejahteraan desa

2) Faktor Eksternal

1. Adanya suatu permohonan dari Bendesa Adat suatu desa yang bertetanggan dengan Desa Pakraman Padangsambian untuk memberikan pinjaman kredit kepada satu atau lebih anggota masyarakat Desa Pakramannya dikarenakan LPD dari Desa Pakraman tersebut telah mencapai batasan dalam memberikan pinjaman kredit.

2. Pinjaman diberikan kepada debitur diluar anggota Desa Pakraman dengan alasan LPD menganut asas kekeluargaan, dimana calon debitur yang dulunya tinggal di Desa Pakraman Padangsambian, namun berpindah tempat tinggal ke daerah lain bahkan ada yang berpindah keluar pulau Bali tetap dapat melakukan pinjaman kredit di LPD Desa Pakraman Padangsambian dikarenakan orang tersebut yang sebelumnya tinggal di Desa Pakraman Padangsambian dianggap sebagai semeton.

3. Permohonan pinjaman kredit oleh calon debitur diluar anggota Desa Pakraman dilakukan oleh LPD Desa Pakraman Padangsambian tanpa adanya kerjasama antar desa 
disebabkan oleh tidak adanya sanksi terhadap pelanggaran tersebut yang dilakukan oleh debitur dan/atau LPD, maka kegiatan tersebut dianggap boleh dilakukan.

LPD Desa Pakraman Padangsambian lebih mementingkan adanya jaminan dari calon debitur untuk memberikan pinjaman kredit. Dalam hal ini LPD lebih dekat kepada fungsinya sebagai bank yang mengutamakan 6C(character, capital, collateral, capacity, condition of economy, constraint) sebagai prinsip pemberian kredit dan lebih tunduk kepada Undang-Undang No 10 tahun 1998 tentang Perbankan yang selanjutnya disebut UU Perbankan, dimana hal ini bertentangan dengan pernyataan I Nyoman Sukandia yang mengatakan Proses pembentukan dan peruntukan keberadaan lembaga keuangan tersebut, demikian juga latar belakang pembentuk dan orientasi-orientasinya, menunjukan sifat komunitas atau lembaga keuangan komunitas yang sangat kuat, yaitu bahwa lembaga tersebut dibentuk dan dikelola oleh, dan untuk Desa Pakraman sebagai suatu bentuk komunitas. ${ }^{7}$

Sifat demikian menunjukan bahwa lembaga keuangan tersebut merupakan suatu lembaga keuangan yang memiliki sifat yang khas dan berada diluar ragam lembaga-lembaga keuangan yang diatur oleh UU Perbankan, atau Undang-Undang Nomor 1 tahun 2013 tentang Lembaga Keuangan Mikro yang selanjutnya disebut UU LKM, Bahwa ketentuan pada Pasal 39 ayat (3) UU LKM yang menyatakan Lembaga Perkreditan Desa dan Lumbung Pitih Nagari serta lembaga sejenis yang telah ada sebelum undang undang ini berlaku, dinyatakan diakui keberadaannya berdasarkan hukum adat dan tidak tunduk pada undang -

${ }^{7}$ I Nyoman Nurjaya, dkk, op. Cit., h. 65. 
undang ini. ${ }^{8}$ Karena itu tidak dapat secara serta merta LPD ditempatkan dibawah pengaturan UU Perbankan maupun UU LKM. ${ }^{9}$ LPD harus mengedapankan ketentuan yang tercantum dalam Perda No 3 tahun 2017 tentang LPD sebelum melihat kepada aturan lain.

\section{PENUTUP}

\subsection{Kesimpulan}

Pelaksanaan pasal 7 ayat (1) huruf c Perda No 3 tahun 2017 tentang LPD kurang efektif, dimana tidak terdapat adanya kerjasama antar desa dalam prasyarat permohonan pinjaman kredit bagi calon debitur diluar anggota desa, kendala yang ditemukan dalam pelaksanaan ketentuan tersebut adalah ketidaktahuan mengenai hukum yang berlaku, diutamakan adanya jaminan, serta tidak adanya sanksi terkait pelanggaran yang terjadi. Faktor penyebab diperbolehkannya debitur diluar anggota desa melakukan pinjaman kredit di LPD Desa Pakraman Padangsambian adalah LPD masih menggunakan ketentuan Perda lama yang telah tidak berlaku, lebih mementingkan adanya jaminan berupa agunan dari calon debitur, LPD mementingkan banyaknya pinjaman kredit dengan bunga yang banyak sehingga dapat menjamin kesejahteraan desa, serta lebih diutamakannya asas kekeluargaan sehingga mengesampingkan ketentuan yang mengatur.

\subsection{Saran}

Saran yang dapat diberikan berdasarkan kesimpulan diatas adalah LPD seharusnya mengedepankan ketentuan dalam Perda No 3 tahun 2017 tentang LPD sebelum melihat kepada ketentuan

\footnotetext{
${ }^{8}$ I Gede Made Gandhi Dwinata dkk, op. Cit..,h. 4..

${ }^{9}$ I Nyoman Nurjaya, dkk, op. Cit.., h. 98.
} 
lainnya. mengutamakan prinsip kehati-hatian dan SOP tersendiri dalam memberikan pinjaman kepada debitur diluar anggota Desa Pakraman serta perlu adanya peran pemerintah dalam memperbaharui peraturan mengenai LPD yang berlaku agar lebih kompleks mengatur mengenai sanksi terkait pelanggaran dalam perjanjian kredit sehingga hal tersebut tidak terjadi kembali dikemudian hari. 


\section{DAFTAR PUSTAKA}

\section{Buku-buku}

Bambang Sunggono, 2003, Metodologi Penelitian Hukum, PT Raja Grafindo Perkasa, Jakarta.

Nurjaya, I Nyoman, dkk, 2011, Landasan Teoritik Pengaturan LPD Sebagai Lembaga Keuangan Komunitas Masyarakat Hukum Adat Di Bali, Udayana University Press, Denpasar

Sri rahayu Gorda, A. A. Ngr, 2016, Wrddhi Grhiyad Prinsip Perjanjian Kredi Mmenurut Hindu, Udayana Press, Denpasar

Udiana, I Made, 2015, Kedudukan Dan Kewenangan Pengadilan Hubungan Industrial, Udayana University Press, Denpasar

\section{Peraturan Perundang-Undangan}

Indonesia, Undang-Undang Republik Indonesia Nomor 10 Tahun 1998 Tentang Perbankan. Dimuat dalam Lembaran Negara Republik Indonesia Tahun 1998 Nomor 182, Tambahan Lembaran Negara Republik Indonesia Nomor 3790.

Undang-Undang Republik Indonesia Nomor 1 Tahun 2013 tentang Lembaga Keuangan Mikro. Lembaran Negara Republik Indonesia Tahum 2013 Nomor 12, Tambahan Lembar Negara Republik Indonesia Nomor 5394.

Bali, Peraturan Daerah Provinsi Bali Nomor 3 Tahun 2017 Tentang Lembaga Perkreditan Desa. Dimuat dalam Lembaran Daerah Provinsi Bali Tahun 2017 Nomor 3, Tambahan Lembaran Daerah Provinsi Bali Nomor 3.

\section{Internet}

https://id.wikipedia.org/ (diakses pada tanggal 20 Mei 2019)

I Gede Made Gandhi Dwinata dkk, 2015,"Eksistensi Lembaga Perkreditan Desa Setelah Dikeluarkannya Undang - Undang Nomor 1 Tahun 2013 Tentang Lembaga Keuangan Mikro", Jurnal Fakultas Hukum Universitas Udayana, Denpasar, h. 2. URL : http s://ojs.unud.ac.id/.index.php/kerthasem aya/.article/download/13163/8845. Diakses tanggal 20 Mei 2019.

Komang Gede Indra Parisuda dkk, 2013, "Pelaksanaan Pemberian Kredit Kepada Anggota Masyarakat Pada Lembaga Perkreditan Desa Di Kota Denpasar", Jurnal Fakultas Hukum Universitas Udayana, Denpasar, h. 1. URL: https://ojs.unud.ac.id/index.php/kerthasemaya/article/vie $\underline{\mathrm{w} / 5256}$. Diakses tanggal 22 Mei 2019 